\title{
The influence of metacognitive training on the improvement of working memory in children with ADHD
}

\author{
Wpływ treningu metakognitywnego na poprawę pamięci operacyjnej u dzieci z ADHD
}

Natalia Kajka ABCDEF https://orcid.org/0000-0002-1781-6773

Department of Psychotherapy and Health Psychology, The John Paul II Catholic University of Lublin

\begin{abstract}
The purpose of the study is to check whether the memory will be strengthened after three months of metacognitive training using such mnemonic techniques as Mind Maps and Sketchnoting in children diagnosed with ADHD. According to the most recent, the Fifth Edition of The Diagnostic and Statistical Manual of Mental Disorders, working memory plays a key role both in the symptoms of ADHD and in secondary problems such as: learning disorders, professional or social difficulties.

Method: 45 schoolchildren took part in the experimental study $(M=10.41 ; S D=1.42)$. Each child had a diagnosed psychomotor overexcitability and attention disorders. The participants were randomly qualified into three groups: the first group was tested for the effect of Mind Maps; the second group, for the effect of Sketchnoting while the third group was assigned the role of a control group. All of the groups were administered The Deferred Naming Test before and after the training. This assessment method belongs to the PU-1 Set of Diagnostic Tests.

Results: The working memory improved in each of the three groups. The smallest number of errors were made by the children in the group with Mind Maps, while the biggest number of errors were made by the children in the control group.

Conclusion: Mind Maps can be an important complement to other forms of therapeutic treatment for children with ADHD diagnosis. Regular use of this tool in education or therapy strengthens the memory. The improvement of this executive function can be substantial in learning to write and read (memorization of the correct shapes of letters), remembering and recalling from memory the rules agreed with the child or better time orientation.
\end{abstract}

Keywords: working memory, metacognitive training, ADHD, Mind Maps, Sketchnoting

\section{Streszczenie}

Celem badania jest sprawdzenie, czy pamięć operacyjna wzmocni się po trzymiesięcznym treningu metapoznawczym z użyciem takich mnemotechnik jak: Mapy Myśli i Notatka Rysunkowa u dzieci z diagnozą ADHD. W aktualnej klasyfikacji zaburzeń psychicznych DSM 5 przypisuje się kluczową rolę pamięci operacyjnej zarówno w objawach ADHD jak również wtórnie w problemach takich jak: zaburzenia uczenia się, trudnościach zawodowych czy społecznych.

Metoda: W badaniu eksperymentalnym wzięło udział 45 dzieci w wieku szkolnym $(M=10,41 ; S D=1,42)$. Każde dziecko posiadało zdiagnozowany zespół nadpobudliwości psychoruchowej z zaburzeniami uwagi. Uczestnicy zostali losowo zakwalifikowani do trzech grup: ze stymulacją Mapami Myśli, Notatką Rysunkową i do grupy kontrolnej. Wszyscy zostali zbadani Testem Odroczonego Nazywania przed i po treningu. Narzędzie to należy do Baterii Diagnozy Funkcji Poznawczych PU-1.

Wyniki: Pamięć operacyjna poprawiła się w każdej z trzech grup. Najmniej błędów popełniały dzieci będące w grupie z Mapami Myśli natomiast najwięcej błędów miały dzieci z grupy Kontrolnej.

Wniosek: Mapy Myśli mogą stanowić istotne uzupełnienie innych form pomocy terapeutycznych dla dzieci z diagnozą ADHD. Regularne stosowanie narzędzia w edukacji, czy terapii wzmacnia pamięć operacyjną. Poprawa tej funkcji wykonawczej może być znacząca w nauce pisania i czytania (zapamiętywanie prawidłowych kształtów liter), zapamiętywania i przywoływania z pamięci ustalonych z dzieckiem zasad, czy lepszej orientacji czasowej.

Słowa kluczowe: pamięć operacyjna, trening metakognitywny, ADHD, Mapy Myśli, Sketchnoting 


\section{Introduction}

In recent years, a revival and improvement of the concepts explaining the causal mechanisms of symptoms of attention deficit hyperactivity disorder (ADHD) have been observed [1,2]. The continuing interest in this subject indicates its importance. Basic performance impairment is the most commonly observed symptom in patients diagnosed with ADHD [3,4]. Children with these dysfunctions do only experience cognitive difficulties, but are also less socially self-sufficient [4]. This means difficulties in self-care, independent performance of tasks, cooperation in a peer group or effective organization of one's time [5]. Unfortunately, the nature of these difficulties means that pharmacotherapy alone is insufficient, and the psychotherapy of a child with ADHD and his/her family is often referred to as mere palliative treatment in research literature [6]. Psychological and medical support is undoubtedly necessary. However, when evaluating the child's treatment progress in retrospect, it turns out that while the intensity of symptoms decreases, functioning in adulthood is still full of chaos, awkwardness and numerous failures. This often leads the patient to increasing difficulties in the personal and socioeconomic sphere, as well as to addictions or depression [7]. Fortunately, many experimental studies indicate that the nature of executive functions is not static and under the influence of appropriate stimulation these functions are improved $[4,8,9]$.
In the last decade, the working memory training has become particularly popular. This executive function is responsible for storing, maintaining and manipulating information that is essential for the management of behavior [9]. It is a kind of cache allowing you to create plans and perform targeted actions at the right time [10]. According to the most recent, the Fifth Edition of The Diagnostic and Statistical Manual of Mental Disorders, working memory plays a key role both in the symptoms of ADHD and in secondary problems such as: learning disorders, professional or social difficulties [9,11]. Interventions aimed at improving this cognitive ability may therefore be of crucial importance in the treatment of ADHD and the numerous extracriteria difficulties experienced by patients [12].

It should be noted that different types of trainings in which children participate can be found in the research literature. Most often, the research points to the efficiency of cognitive interventions $[13,14]$. These interventions are defined as regularly performed exercises aimed at improving the basic elements of cognitive processes by stimulating the mechanisms underlying them [15]. However, researchers Antshel, Hier and Barkley encourage interventions involving children with ADHD to focus not only on single-function trainings but also on practical exercises necessary in their everyday life [16].

Therefore, an alternative form of cognitive training is metacognitive training. It seems to fully meet the needs of

Figure 1. Sample Mind Map drawn by a participant in a survey on the Explorer

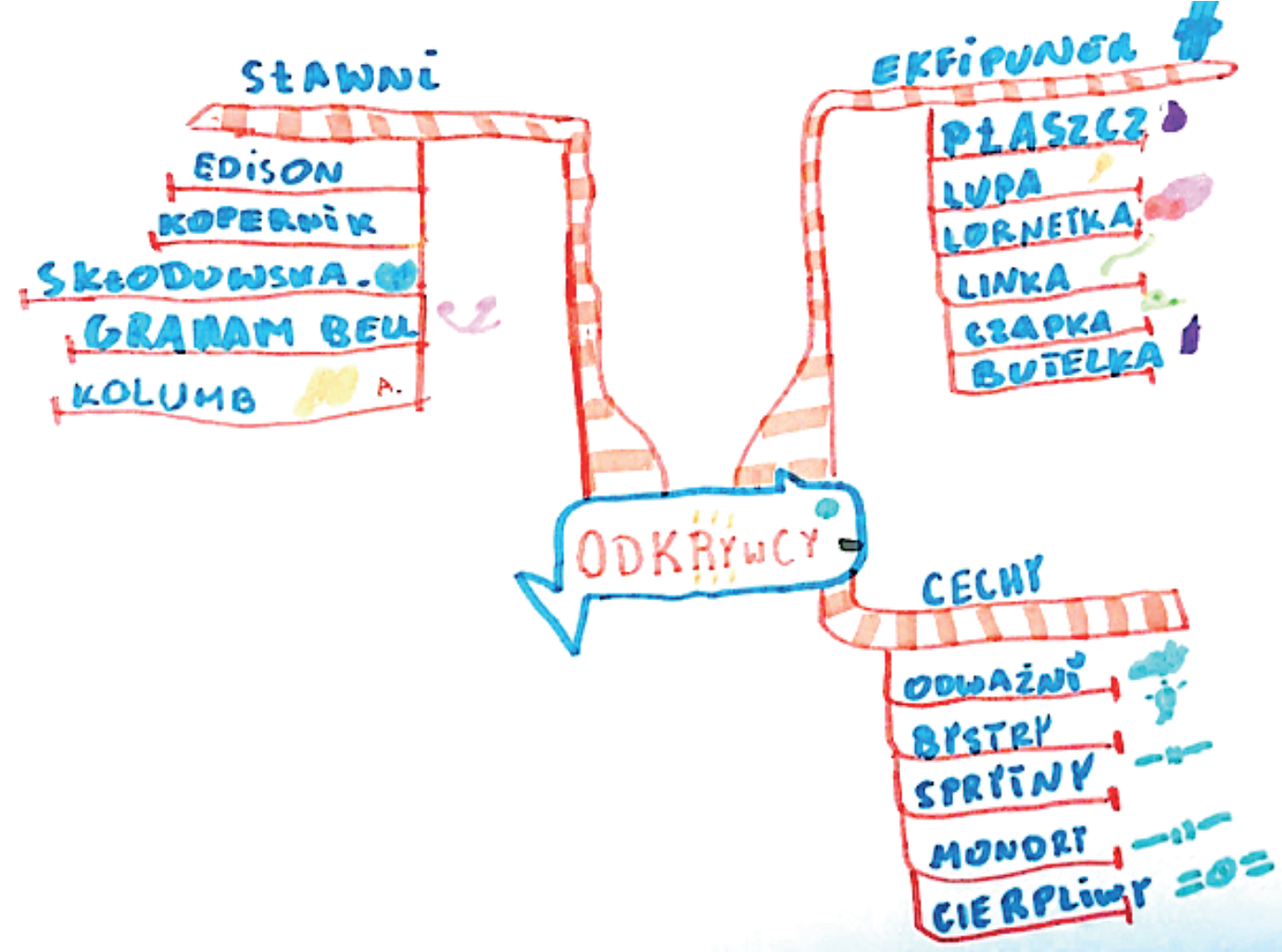


children with ADHD. The aim of this cognitive-behavioral technique is to overcome difficulties at the level of the patient's self-awareness, i.e. to make the patient aware of both his/her resources and weaknesses, to stimulate motivation to overcome problems related to planning and control of his/her deliberate actions [17].

The aim of the research is to check whether the working memory will be strengthened after three months of metacognitive training with the use of such mnemonics as Mind Maps and Sketchnoting. Both tools are effective learning tools commonly used in education.

Mind Map is a kind of graphic-drawing note that resembles an octopus when you look at it. The main concept that the child is working on is first drawn in the center of a blank page. Next, associated representations of ideas such as images or words are added as "limbs" attached to the main concept [18]. Gradually, more limbs branching out from these secondary associated ideas are drawn in a similar way, creating a whole web of concept connections and definitions. This tool is based on the double coding of information (written text and image), thanks to which the child can better remember their content $[18,19]$. With the help of the Mind Map, each major concept is divided into smaller sections. This allows the child to build awareness of the structure of each task [20, 21]. Mind Maps become an attractive form of planning and setting real goals as well as better and more permanent remembering [18]. Thus, they fulfill all the principles of the metacognitive training strategy.

The same applies to the mnemonic technique called Sketchnoting. It is also considered to be one of the methods facilitating remembering and extracting necessary information at the right time [22]. This kind of taking notes allows us to understand the problem better and generate ideas for problem solving. The aim of creating such a transcript of the content is to capture the main idea, its characteristics: to understand the relations between the drawn concepts and other key words [23]. Drawing notes, however, does not take such a well-structured form as Mind Maps do. In this study, children in the Sketchnoting group are not to use words, but only images. The drawn symbols are a consequence of visual thinking and will help the child to keep in memory the information that the child is currently using $[23,24]$.

Thus, the question posed by the research is whether metacognitive training with the use of Mind Maps and Sketchnoting will improve the operating memory in children with ADHD. The research literature indicates that the above tools are commonly used in education, but that they are also recommended for students with special educational needs (including children with ADHD) [25, 26]. If metacognitive training turned out to be an effective approach, it would bring opportunities for its application within the scope of the therapy, either at home or at school, for children diagnosed with ADHD.

Figure 2. Sample Sketchnote drawn by a participant in a survey on the Explorer

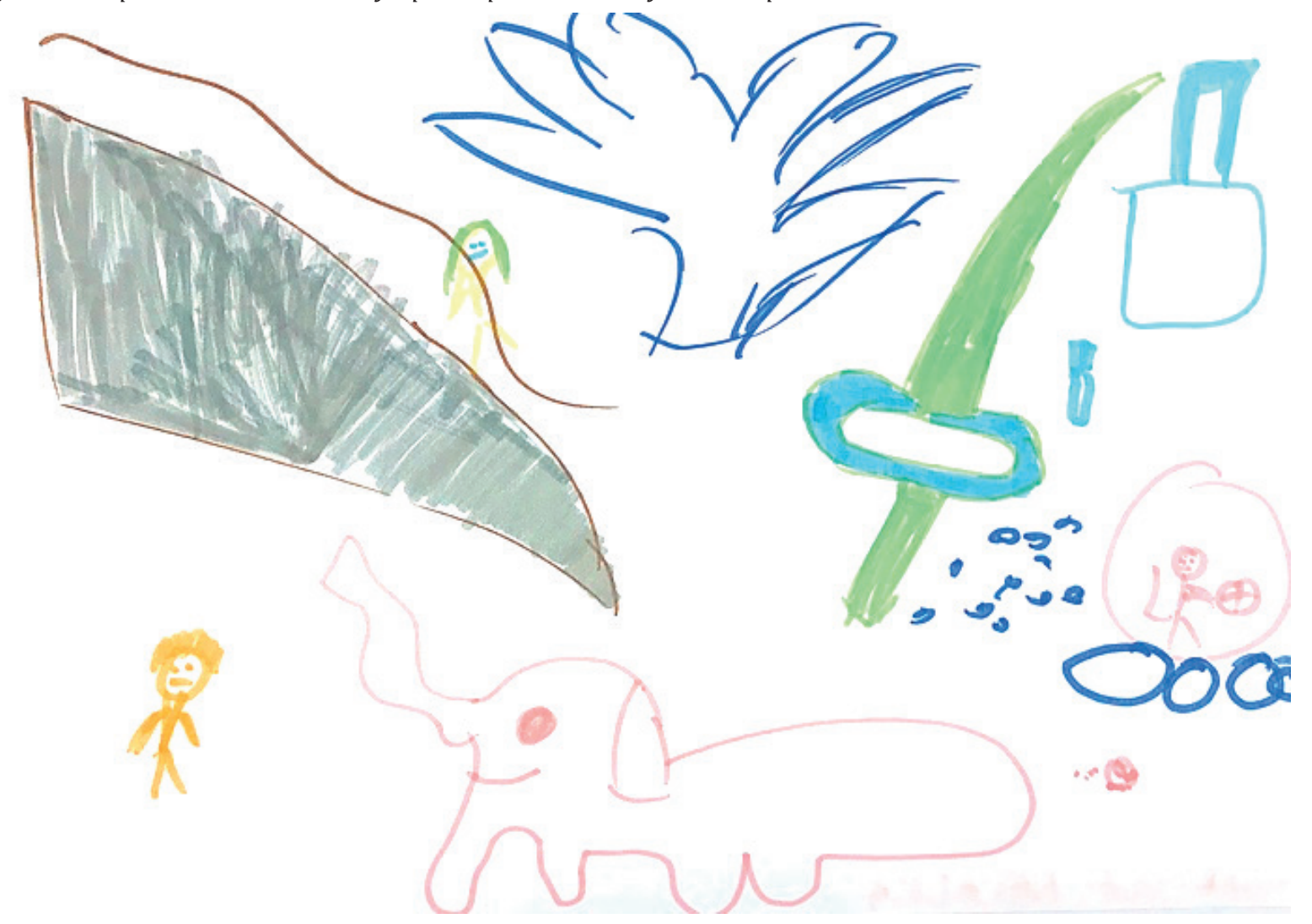




\section{Material and methods:}

The experimental study involved 45 school age children $(M=10.41 ; S D=1.42)$ diagnosed with ADHD. The subjects were randomized to two experimental groups and one control group. Children from the experimental group participated in a 25-hour cycle of classes (with a total time of approx. 3 months). The classes were held twice a week at the John Paul II Catholic University of Lublin. The first group took part in metacognitive training with the use of Mind Maps while the second with the use of Sketchnoting technique. The control group consisted of children who were evaluated in two tests with a three-month interval and did not participate in the above trainings. It is worth noting that children from the control group are also children diagnosed with ADHD. The participants were administered the Deferred Naming Test before and after 3 months of training in order to measure the performance of their working memory. The Deferred Naming Test is an assessment included in the PU-1 Set of Diagnostic Tests and consists in showing the child colorful pictures and the child's task is to tell what picture he or she saw two pictures before. The whole test lasts about $60-90$ seconds. The minimum value of this indicator is 0 while the maximum is 13 . The analysis of this test proved its reliability (Cronbach alpha value $=0.82$ ). It is also worth noting that the PU-1 Set of Diagnostic Tests has been recommended in clinical psychology [28]. The whole project was approved by the Ethics and Research Commission of the Institute of Psychology of the Catholic University of Lublin. Individuals qualified for the study took part in it voluntarily, and the parents of the children gave their written consent both to the anonymous study of the children, as well as to the subsequent publication of the results of the research.

\section{Statistical analysis - calculation methods}

This study examined whether metacognitive training would significantly improve working memory in children with ADHD. To this end, analysis of variance (ANOVA) was performed on all participants at the beginning of the study to check if the subject grouping is homogeneous. A nonparametric statistical hypothesis test (Wilcoxon) was then performed to check the differences between the first and second measurements for each group separately (Mind Maps, Sketchnoting, control). ANOVA analysis was carried out as the next step to check the differences between the first and second working memory assessments for each group (Mind Maps, Sketchnoting, control). The results of these analyses are presented below.

\section{Results}

The range of errors made by children in the Deferred Naming Test ranges from 0 to 8 (out of 13 possible) (Tab.1).
The lowest number of errors was made by children in the Sketchnoting group $(M=1.33 ; S D=1.23)$ and the highest number of errors was made by children from the control group $(M=2.3 ; S D=2.52)$. Despite this, no significant statistical differences were found between the groups $(F=(2.42)=0.995 ; p=$ n.i. $)$.

Table 1. Presentation of average results for the working memory variable as measured by the Deferred Naming Test

\begin{tabular}{|c|c|c|c|c|}
\hline \multicolumn{5}{|c|}{ WORKING MEMORY } \\
\hline & $\begin{array}{l}\text { Mind } \\
\text { Maps }\end{array}$ & Drawnings & Control & Standards* \\
\hline$M$ & 1.70 & 1.33 & 2.3 & \multirow{4}{*}{$1-5$} \\
\hline$S D$ & 1.50 & 1.23 & 2.52 & \\
\hline Minimum & 0 & 0 & 0 & \\
\hline Maksimum & 5 & 4 & 8 & \\
\hline ANOVA & \multicolumn{4}{|c|}{$F(2,42)=0,995 p=n . i}$. \\
\hline
\end{tabular}

*These standards were adopted for the average age of children $(M=10.41)$. The entered numbers refer to the average result

It was then checked whether the working memory had improved between the first and second measurements in each of the three groups: Mind Maps, Sketchnoting and in the Control group.

Table 2. Comparison of average results for the working memory variable in the first and second measurement

\begin{tabular}{|c|c|c|c|c|c|c|}
\hline \multicolumn{7}{|c|}{ WORKING MEMORY } \\
\hline Group & \multicolumn{2}{|c|}{ Mind Maps } & \multicolumn{2}{|c|}{ Drawnings } & \multicolumn{2}{|c|}{ Control } \\
\hline Measurement & $I$ & II & $I$ & II & $I$ & II \\
\hline$Z$ & \multicolumn{2}{|c|}{3.0} & \multicolumn{2}{|c|}{2.81} & \multicolumn{2}{|c|}{2.13} \\
\hline $\boldsymbol{P}$ & \multicolumn{2}{|c|}{0.001} & \multicolumn{2}{|c|}{0.002} & \multicolumn{2}{|c|}{0.02} \\
\hline$M$ & 1.70 & 0,2 & 1.33 & 0.6 & 2.3 & 1.4 \\
\hline$S D$ & 1.50 & 0.56 & 1.23 & 0.91 & 2.52 & 1.68 \\
\hline Me & 0 & 0 & 0 & 0 & 0 & 1 \\
\hline Minimum & 5 & 0 & 4 & 0 & 8 & 0 \\
\hline Maksimum & 1.70 & 2 & 1.33 & 3 & 2.3 & 7 \\
\hline
\end{tabular}

The results (shown in Table 2) indicate statistically significant differences in mean scores after the first and second measurement in each of the three groups: Mind Maps $\left(M_{1}=1.70 ; S D_{1}=1.50 ; M_{2}=0.2 ; S D_{2}=0.56\right)$, Sketchnoting $\left(M_{1}=1.33 ; S D_{1}=1.23 ; M_{2}=0.6 ; S D_{2}=0.91\right)$ and Control group $\left(M_{1}=2.3 ; S D_{1}=2.52 ; M_{2}=1.4 ; S D_{2}=1.68\right)$. A ranked two-series correlation coefficient, determining the range of the effect, was computed for each of the groups. Its value indicates that the effects are considerably meaning that the children who participated in the training with Mind Maps and Sketchnotes make significantly fewer errors in the second 
measurement, and the quantitative effect $\left(r_{c}=0.78 ; r_{c}=\right.$ 0.73 , respectively) is high and greater than the results of children who did not undergo any stimulation $\left(r_{c}=0.55\right)$.

The last step was to check whether the differences between the groups are statistically significant. It can be concluded from the analysis of the presented results (Tab. 3) that there are statistically significant differences ( $p=0.021)$ in the level of working memory after training between groups.

The number of errors which is the working memory

Table 3. Comparison of average results for the working memory variable in the second measurement

\begin{tabular}{|c|c|c|c|}
\hline \multicolumn{5}{|c|}{ W O R K I N G M E M O R Y } \\
\hline & Mind Maps & Drawnings & Control \\
\hline M & 0.2 & 0.6 & 1.4 \\
\hline SD & 0.56 & 0.91 & 1.68 \\
\hline Me & 0 & 0 & 1 \\
\hline Minimum & 0 & 0 & 0 \\
\hline Maksimum & 2 & 3 & 7 \\
\hline ANOVA & \multicolumn{3}{|c|}{$F(2,42)=4,230 ; p=0,021$} \\
\hline \multicolumn{4}{|c|}{$M M>K$} \\
\hline
\end{tabular}

indicator in the Mind Maps group $(M=0.2 ; S D=0.56)$ is significantly lower ( $p=0.02$ respectively) than in the Control group $(M=1.4 ; S D=1.68)$. However, there are no statistically significant differences between the Mind Maps and Sketchnoting group compared with the Sketchnoting and Control group. The effect measured by analysis of variance (ANOVA) points to the fact that the influence of Mind Maps amounts to a decrease of $13 \%$ in the number of errors. This influence should be considered as insignificant.

This means that children from the Mind Maps group made significantly fewer mistakes than children from the Control group, but only $13 \%$ of these results can be attributed to training with Mind Maps $\left(\omega^{2}=0.13\right)$.

Discussion

The analysis showed that the memory has improved significantly in children from all three groups. These results are explained in the research literature. Diamond and Lee write that this particular executive function develops very expressively in school-age children and even stimulations such as physical exercise during physical education classes can have a significant impact on its development [14]. Other researchers emphasize that not only diverse stimulation is important (memory tasks, learning new information), but the regularity of activities undertaken during time is also important [29]. The children from training groups had the opportunity to regularly and systematically exercise their working memory: more so than the children from the control group. This is evidenced by the differences in the number of mistakes made in the assessments of their working memory. The smallest number of errors in the second measurement was found in children from the Mind Maps group, the average number of errors was found in children from the Sketchnoting group, and the biggest number of errors was found in children from the Control group. It is also worth noting that children from the Sketchnoting group had the smallest number of errors at the beginning. On the other hand, children from the group of Mind Maps scored, on average, nearly two errors at the outset of the study. Nevertheless, stimulation with Mind Maps proved to be the most effective.

The conducted research has shown that metacognitive training with the use of Mind Maps and Sketchnotes significantly reduces the number of mistakes made by children in terms of remembering. However, only stimulation with Mind Maps significantly differentiates the results obtained in the group with this kind of memory stimulation from the control group. These conclusions indicate that this method may be an important complement to other forms of treatment for children with diagnosis. In the future, it would be worthwhile to check the influence of metacognitive training on other executive functions in children with ADHD and to conduct a study with larger research group. The clinical size of the experimental sample $(3 \times N=15)$ is a significant limitation of these studies. Nevertheless, the study provides a basis for further exploration, and enhanced working memory may translate into improved skills of children with ADHD, such as: improved literacy skills (remembering the correct shapes of letters), more efficient remembering and recalling of established rules, or better time orientation [10].

\section{Acknowledgments}

The author of this article would like to thank Agnieszka Kulik PhD for her invaluable help and substantive discussions on the drafted scientific text.

The research was a part of a doctoral thesis carried out within the research task "Health promotion among children and teenagers (with ADHD) using Mind Maps" ("Promocja zdrowia wśród dzieci i młodzieży (z ADHD) za pomocq Map Myśli."). 


\section{Wstęp}

W ostatnich latach zaobserwowano odrodzenie i udoskonalenie koncepcji mających wytłumaczyć mechanizmy przyczynowe objawów zespołu nadpobudliwości psychoruchowej z zaburzeniami uwagi (ADHD) [1,2]. Niegasnące zainteresowanie tą tematyką wskazuję na jej ważność. U pacjentów $\mathrm{z}$ diagnozą najczęściej upatruje się mechanizmu podstawowego w zaburzonym działaniu wykonawczym [3,4]. Dzieci, u których występują te dysfunkcje, będę przejawiały nie tylko trudności natury poznawczej, ale także będą mniej samowystarczalne społecznie [4]. Rozumie się przez to trudności w samoopiece, samodzielnym wykonywaniu zadań, współpracy w grupie rówieśniczej czy efektywnym organizowaniu swojego czasu [5]. Niestety natura tych trudności powoduje, że sama farmakoterapia jest niewystarczająca, a psychoterapia dziecka z ADHD i jego rodziny $\mathrm{w}$ literaturze jest określana czasem zabiegami paliatywnymi [6]. Wsparcie psychologiczne i medyczne jest niewątpliwie potrzebne. Jednak oceniając postępy dziecka z diagnozą z perspektywy czasu okazuje się, że o ile nasilenie objawów się zmniejsza to funkcjonowanie w wieku dorosłym jest wciąż pełne chaosu, nieporadności i licznych porażek. Prowadzi to pacjenta niejednokrotnie do narastających trudności w sferze osobistej, społecznoekonomicznej a także do uzależnień czy depresji [7]. Na szczęście wiele badań eksperymentalnych wskazuje, że konstrukt funkcji wykonawczych nie jest statyczny i pod wpływem odpowiedniej stymulacji dochodzi do poprawy tych funkcji $[4,8,9]$.

W ostatniej dekadzie szczególnym zainteresowaniem cieszy się trening pamięci roboczej. Ta zarządzająca funkcja odpowiada za przechowywanie, utrzymywanie ale także manipulowanie informacjami, które są istotne dla kierowania zachowaniem [9]. To rodzaj bufora pozwalający na tworzenie planów, wykonywanie działań celowych w odpowiednim czasie [10]. W aktualnej klasyfikacji zaburzeń psychicznych DSM 5 przypisuje się kluczową rolę pamięci operacyjnej zarówno w objawach ADHD jak również wtórnie $\mathrm{w}$ problemach takich jak: zaburzenia uczenia się, trudnościach zawodowych czy społecznych $[9,11]$. Interwencje mające na celu poprawę tej zdolności poznawczej mogą mieć zatem newralgiczne znaczenie w leczeniu ADHD oraz licznych trudności pozakryterialnych, z którymi borykają się pacjenci [12].

Należy zwrócić uwagę, że w literaturze przedmiotu można spotkać różne rodzaje treningów, w których biorą udział dzieci. Najczęściej badania wskazują na skuteczność interwencji kognitywnych [13, 14]. Definiuje się je jako regularne ćwiczenia, które mają za zadanie poprawiać podstawowe elementy procesów poznawczych poprzez stymulowanie mechanizmów leżących u ich podstaw [15]. Natomiast badacze Antshel, Hier i Barkley zachęcają aby interwencje, którymi są obejmowane dzieci z ADHD koncentrowały się nie tylko na treningach pojedynczych funkcji, a na wykonywaniu praktycznych ćwiczeń

Ryc. 1 Przykładowa Mapa Myśli narysowana przez uczestnika badania na temat Odkrywcy

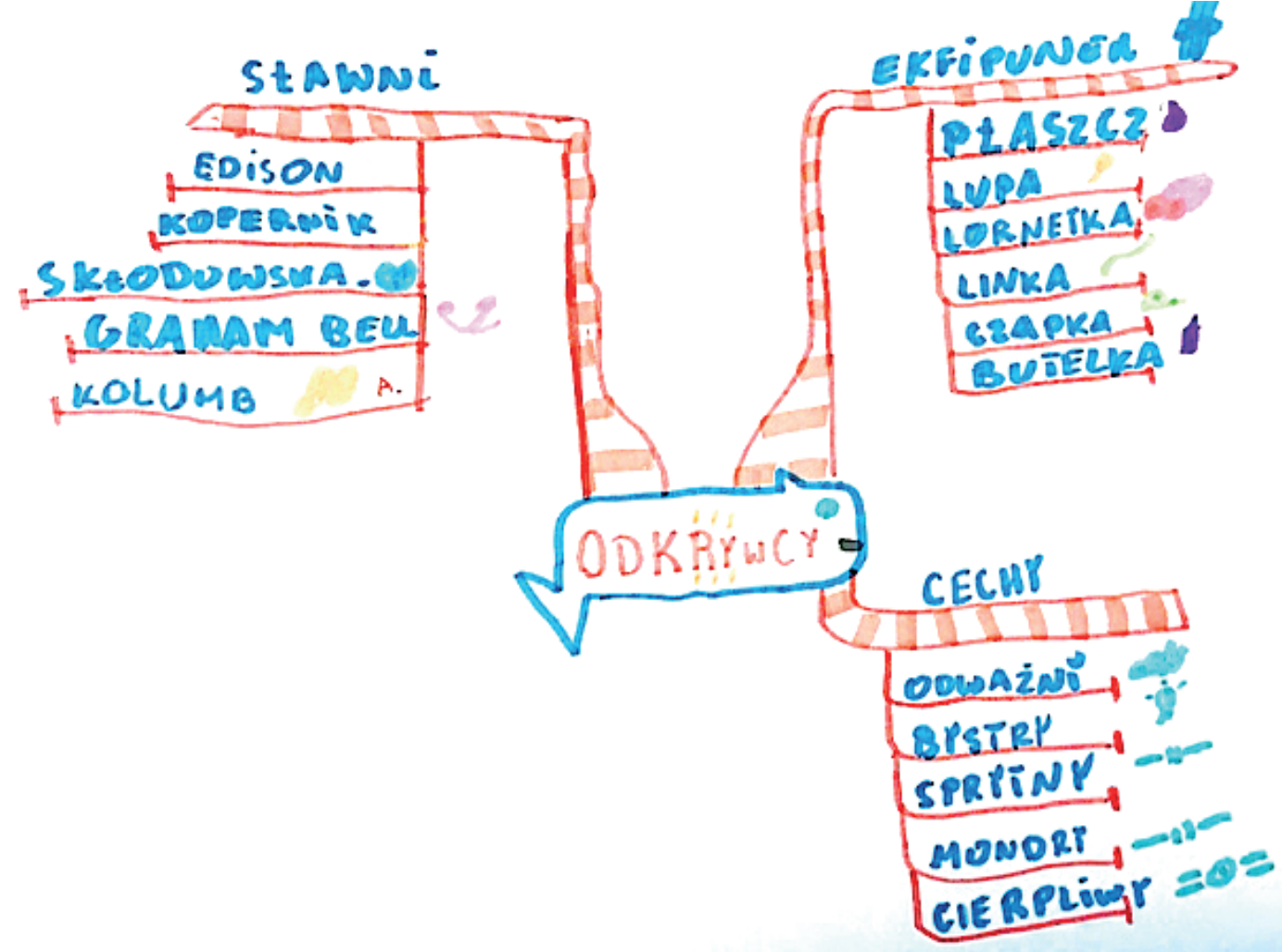


potrzebnych dzieciom w codziennym funkcjonowaniu [16].

Dlatego alternatywną formą dla treningu poznawczego jest szkolenie metakognitywne. Wydaje się ono w pełni odpowiadać potrzebom dzieci z ADHD. Jest to technika pracy należąca do metod poznawczo - behawioralnych. Jej celem jest pokonanie trudności na poziomie samoświadomości pacjenta, czyli uzmysłowienie mu zarówno jego zasobów jak i słabych stron, uruchomienie motywacji do pokonania problemów związanych z planowaniem i kontrolą swoich działań celowych [17].

Celem badań jest sprawdzenie, czy pamięć operacyjna wzmocni się po trzymiesięcznym treningu metapoznawczym z użyciem takich mnemotechnik jak: Mapy Myśli i Notatka Rysunkowa. Obydwa narzędzia są strategiami efektywnej nauki powszechnie stosowanymi w edukacji.

Mapy Myśli to rodzaj graficzno-rysunkowej notatki, która przypomina swoim wyglądem ośmiornice. $\mathrm{Na}$ środku kartki znajduje się główny temat, który opracowuje dziecko. Następnie od tego zagadnienia wyprowadza się pierwszą kończynę, której nadaje się tytuł i tworzy się do niej spis skojarzeń z nią związanych za pomocą kluczowych słów i rysunków [18]. Stopniowo dorysowuje się kolejne kończyny i zapełnia się je w sposób analogiczny. To narzędzie bazuje na podwójnym kodowaniu informacji (tekstu pisanego i obrazu), przez co dziecko możne lepiej zapamiętać notowaną na nich treść $[18,19]$. Za pomocą Mapy Myśli, każde duże zagadnienie jest podzielone na mniejsze części. Pozwala to dziecku budować świadomość struktury każdego zadania [20, 21]. Mapy Myśli stają się atrakcyjną formą planowania i stawiania sobie realnych celów a także lepszego i trwalszego zapamiętywania [18]. Realizują tym samym wszystkie założenia strategii metakognitywnej.

Nie inaczej jest w przypadku Notatki Rysunkowej. To również metoda uznawana za jedną z mnemotechnik wspomagającą zapamiętywanie i wydobywanie potrzebnych informacji w odpowiednim czasie [22]. Taki rodzaj notatek pozwala zrozumieć lepiej opracowywane zagadnienie i wygenerować pomysły na rozwiązanie problemu. Celem tworzenia takiego zapisu treści jest uchwycenie głównej idei, jej charakterystyki, zrozumienie relacji między rysowanymi zagadnieniami a innymi kluczowymi hasłami [23]. Rysunkowe zapiski nie mają jednak uporządkowanej struktury, tak jak Mapy Myśli. W tym badaniu dzieci z grupy Notatki Rysunkowej nie będą używać słów. Będą się posługiwać jedynie obrazami. Narysowane symbole są konsekwencją myślenia wizualnego i będą pomagać dziecku utrzymywać w pamięci informacje, którymi właśnie ono operuje [23, 24].

Zatem pytaniem badawczym jest, czy trening metapoznawczy z zastosowaniem Map Myśli i Notatką Rysunkową poprawi pamięć operacyjną u dzieci $\mathrm{z}$

Ryc.2. Przykładowa Notatka Wizualna narysowana przez uczestnika badania na temat Odkrywcy

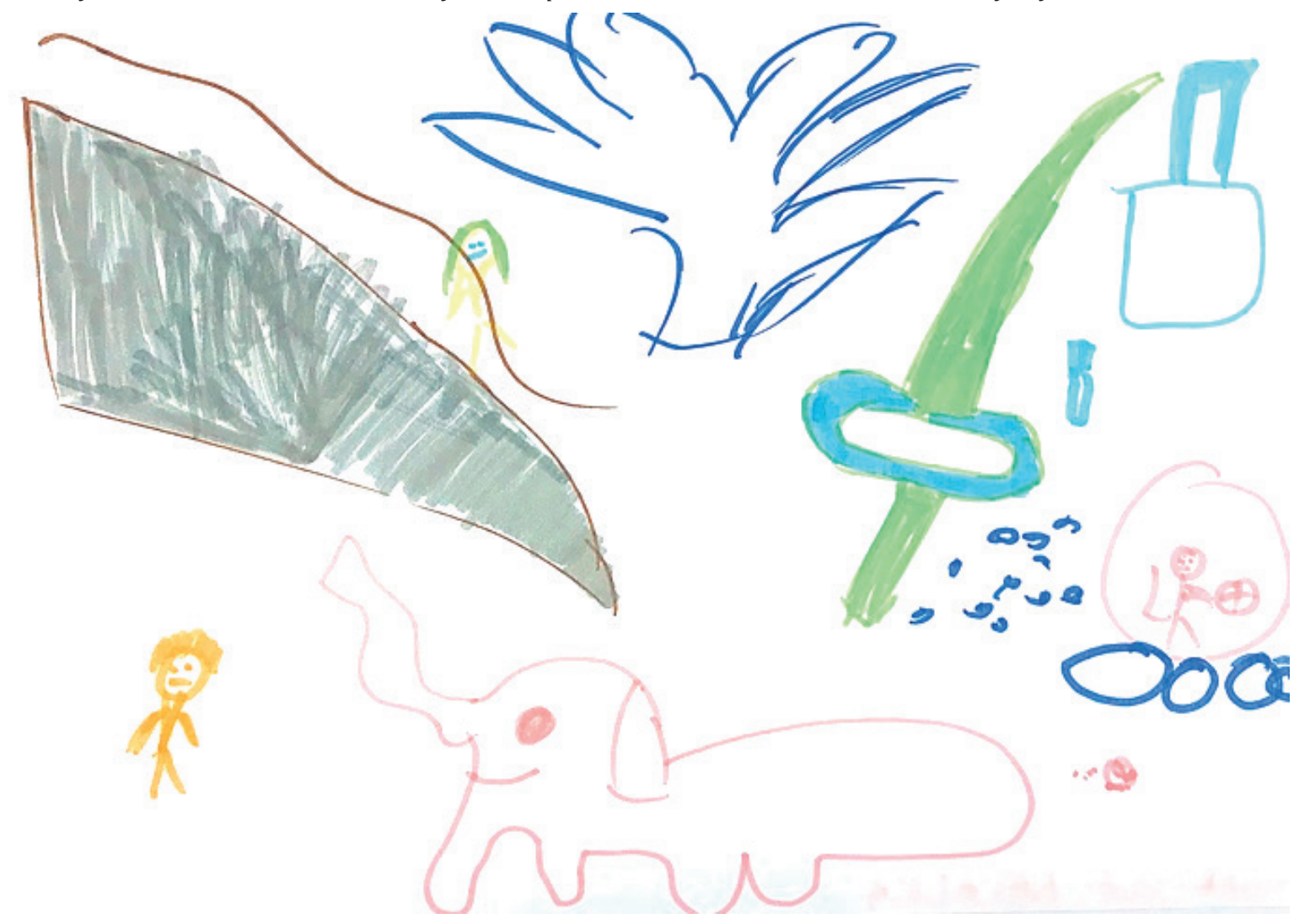


ADHD? Literatura przedmiotu wskazuje, że powyższe narzędzia są powszechnie stosowane w edukacji ale także rekomenduje się je dla uczniów ze specjalnymi potrzebami edukacyjnymi (w tym dzieci z ADHD) [25, 26]. Gdyby szkolenie metakognitywne okazało się skuteczną interwencją niosłoby za sobą możliwości aplikacyjne zarówno w domu, w szkole czy podczas terapii dziecka z ADHD.

\section{Materiał i metoda}

W badaniu eksperymentalnym wzięło udział 45 dzieci w wieku szkolnym $(M=10,41 ; S D=1,42)$ z diagnozą ADHD. Osoby badane zostały losowo dobrane do dwóch grup eksperymentalnych i jednej grupy kontrolnej. Dzieci z grupy eksperymentalnej uczestniczyły w 25 godzinnym cyklu zajęć (całkowity czas ok. 3 miesiące). Zajęcia odbywały się 2 razy w tygodniu w Katolickim Uniwersytecie Lubelskim Jana Pawła II. Pierwsza grupa uczestniczyła $\mathrm{w}$ treningu metapoznawczym $\mathrm{z}$ zastosowaniem Map Myśli. Druga grupa w treningu metapoznawczym z zastosowaniem Notatki Rysunkowej a grupa kontrolna to dzieci, które zostały zbadane $\mathrm{w}$ dwóch pomiarach z trzymiesięcznym odstępem czasu i nie brały udziału w powyższych treningach. Warto zaznaczyć, że dzieci z grupy kontrolnej to również dzieci z diagnozą ADHD. Uczestnicy zostali zbadani przed podjęciem treningu i po upływie 3 miesięcy Testem Odroczonego Nazywania (TON) mierzącym błędy pamięci operacyjnej. Należy on do Baterii Diagnozy Testów Poznawczych PU-1 [27]. TON polega na pokazywaniu dziecku kolorowych obrazków a zadaniem dziecka jest powiedzieć, jaki obrazek widział dwa obrazki wcześniej. Całość testu trwa ok 60 - 90 sekund. Analiza właściwości psychometrycznych $\mathrm{w}$ tym badaniu skoncentruje się na liczbie ponownych startów (błędnych odpowiedziach) Minimalna wartość tego wskaźnika wynosi 0 a maksymalna to 13 . Analiza rzetelności tego testu wykazała, że jest on rzetelny $(\alpha$ Cronbacha $=0,82)$ [27]. Warto też podkreślić, że Bateria Diagnozy Testów PU-1 zyskało rekomendację w dziedzinie psychologii klinicznej [28]. Całość projektu zyskała zgodę Komisji Etyki Badań Naukowych Instytutu Psychologii KUL. Osoby zakwalifikowane do badań brały w nim dobrowolny udział, a rodzice dzieci wyrazili swoją pisemną zgodę zarówno na anonimowe badanie dzieci, jak również późniejsze publikowanie wyników badań naukowych.

\section{Analiza statystyczna - strategia obliczeń}

W tym badaniu sprawdzono czy trening metakognitywny istotnie wpłynie na poprawę pamięci operacyjnej u dzieci z ADHD. W tym celu wykonano analizę wariancji (ANOVA) dla pierwszego pomiaru wszystkich uczestników badania, aby sprawdzić, czy na wstępie grupy są jednorodne. Następnie wykonano nieparametryczny test znaków Wilcoxona celem sprawdzenia różnic między pierwszym a drugim pomiarem dla każdej z grup osobno (Mapy Myśli, Notatka Rysunkowa, Kontrolna). W kolejnym kroku wykonano analizę wariancji ANOVA celem sprawdzenia różnić między grupami po przeprowadzonym treningu pamięci operacyjnej. Poniżej przedstawiono wyniki tych analiz.

\section{Wyniki}

Zakres popełnionych błędów w Teście Odroczonego Nazywania przez dzieci wynosi od 0 do 8 (na 13 możliwych) (Tab.1). Najmniejszą liczbę błędów popełniły dzieci zakwalifikowane do grupy z Notatką Rysunkową $(M=1,33 ; S D=1,23)$ a największą liczbę błędów uzyskały dzieci z grupy Kontrolnej $(M=2,3 ; S D=2,52)$. Mimo tego,

Tab.1. Przedstawienie wyników średnich dla zmiennej pamięć operacyjna mierzonej Testem Odroczonego Nazywania

\begin{tabular}{|c|c|c|c|c|}
\hline \multicolumn{5}{|c|}{ PAM I Ę Ć OPERACY JNA } \\
\hline & $\begin{array}{l}\text { Mapy } \\
\text { Myśli }\end{array}$ & Rysunki & Kontrolna & Normy* \\
\hline$M$ & 1,70 & 1,33 & 2,3 & \multirow{4}{*}{$1-5$} \\
\hline$S D$ & 1,50 & 1,23 & 2,52 & \\
\hline Minimum & 0 & 0 & 0 & \\
\hline Maksimum & 5 & 4 & 8 & \\
\hline ANOVA & \multicolumn{4}{|c|}{$F(2,42)=0,995 p=n . i}$. \\
\hline
\end{tabular}

*Podane normy zostały przyjęte dla uśrednionego wieku dzieci $(M=10,41)$. Wpisane liczby dotyczq wyniku przeciętnego

nie stwierdzono istotnie statystycznych różnic między badanymi grupami $(F=(2,42)=0,995 ; p=$ n.i. $)$.

Następnie sprawdzono, czy pamięć operacyjna uległa poprawie między pierwszym a drugim pomiarem w każdej z trzech grup: Mapy Myśli, Notatka Rysunkowa

Tab. 2. Porównanie wyników średnich dla zmiennej pamięć operacyjna w pierwszym i drugim pomiarze

\begin{tabular}{|c|c|c|c|c|c|c|}
\hline \multicolumn{7}{|c|}{ P A M I E Ć O P E R A C Y J N A } \\
\hline Grupa & \multicolumn{2}{|c|}{ Mapy Myśli } & \multicolumn{2}{c|}{$\begin{array}{c}\text { Notatka } \\
\text { Rysunkowa }\end{array}$} & \multicolumn{2}{|c|}{ Kontrolna } \\
\hline Pomiar & $I$ & $I I$ & $I$ & $I I$ & $I$ & $I I$ \\
\hline $\boldsymbol{Z}$ & \multicolumn{2}{|c|}{3,0} & \multicolumn{2}{|c|}{2,81} & \multicolumn{2}{|c|}{2,13} \\
\hline $\boldsymbol{P}$ & \multicolumn{2}{|c|}{$\mathbf{0 , 0 0 1}$} & \multicolumn{2}{|c|}{$\mathbf{0 , 0 0 2}$} & \multicolumn{2}{c|}{$\mathbf{0 , 0 2}$} \\
\hline $\boldsymbol{M}$ & 1,70 & 0,2 & 1,33 & 0,6 & 2,3 & 1,4 \\
\hline SD & 1,50 & 0,56 & 1,23 & 0,91 & 2,52 & 1,68 \\
\hline Me & 0 & 0 & 0 & 0 & 0 & 1 \\
\hline Minimum & 5 & 0 & 4 & 0 & 8 & 0 \\
\hline Maksimum & 1,70 & 2 & 1,33 & 3 & 2,3 & 7 \\
\hline
\end{tabular}


i w grupie Kontrolnej.

Wyniki (Tab. 2) wskazują na istotne statystycznie różnice $\mathrm{w}$ nasileniu średnich po między pierwszym a drugim pomiarem $\mathrm{w}$ każdej $\mathrm{z}$ trzech grup: Mapy Myśli $\left(M_{1}=1,70 ; S D_{1}=1,50 ; M_{2}=0,2 ; S D_{2}=0,56\right)$, Rysunki $\left(M_{1}=1,33 ; S D_{1}=1,23 ; M_{2}=0,6 ; S D_{2}=0,91\right)$ oraz $\mathrm{w}$ grupie Kontrolnej $\left(M_{1}=2,3 ; S D_{1}=2,52 ; M_{2}=1,4 ; S D_{2}=1,68\right)$. Dla każdej z grup obliczono również rangowy współczynnik korelacji dwuseryjnej określający wskaźnik siły efektu. Jego wartość wskazuje, że efekty są duże. Oznacza to, że dzieci, które uczestniczyły w treningu z Mapami Myśli i Rysunkami popełniają istotnie mniej błędów w drugim pomiarze, a ilościowa siła tego zjawiska (odpowiednio: $\left.r_{c}=0,78 ; r_{c}=0,73\right)$ jest duża i większa od wyników dzieci, które nie podlegały żadnej stymulacji $\left(r_{c}=0,55\right)$.

Ostatnim krokiem było sprawdzenie, czy różnice między grupami są istotne statystycznie. Analizując przedstawione rezultaty (Tab.3) można stwierdzić, iż istnieją istotne statystycznie różnice $(p=0,021)$

Tab. 3. Porównanie wyników średnich dla zmiennej pamięć operacyjna $w$ drugim pomiarze

\begin{tabular}{|c|c|c|c|}
\hline \multicolumn{4}{|c|}{ P A M I E Ć O P E R A C Y J N A } \\
\hline & Mapy Myśli & $\begin{array}{c}\text { Notatka } \\
\text { Rysunkowa }\end{array}$ & Kontrolna \\
\hline $\boldsymbol{M}$ & 0,2 & 0,6 & 1,4 \\
\hline SD & 0,56 & 0,91 & 1,68 \\
\hline Me & 0 & 0 & 1 \\
\hline Minimum & 0 & 0 & 0 \\
\hline Maksimum & 2 & 3 & 7 \\
\hline ANOVA & \multicolumn{3}{|c|}{$F(2,42)=4,230 ; p=0,021$} \\
\hline \multicolumn{3}{|c|}{$M M>K$} \\
\hline
\end{tabular}

w poziomie pamięci operacyjnej po treningu między grupami.

Poziom liczby popełnionych błędów, będących wskaźnikiem pamięci operacyjnej w grupie z Mapami Myśli $(M=0,2 ; S D=0,56)$ jest istotnie niższy (odpowiednio $p=0,02) \quad w$ porównaniu $\mathrm{z}$ grupą Kontrolną $(M=1,4$; $S D=1,68)$. Natomiast nie istnieją istotne statystycznie różnice między grupą Mapy Myśli i Rysunki oraz Notatką Rysunkową i grupą Kontrolną. Siła efektu mierzona dla analizy wariancji (ANOVA) szacuje, iż wpływ Map Myśli w $13 \%$ tłumaczy wzrost pamięci operacyjnej (spadek liczby błędów). Jest to wynik określany jako mały.

Oznacza to, że dzieci z grupy Mapy Myśli popełniły istotnie mniej błędów niż dzieci w grupie Kontrolnej, jednak tylko w 13\% można przypisać ten progres treningom z Mapami Myśli $\left(\omega^{2}=0,13\right)$.

\section{Dyskusja}

Przeprowadzone analizy wykazały, że pamięć operacyjna poprawiła się istotnie u dzieci w każdej z trzech grup. Wyniki te mają swoje uzasadnienie w literaturze. Diamond i Lee piszę, że ta funkcja wykonawcza rozwija się bardzo ekspresyjnie u dzieci w wieku szkolnym i nawet takie stymulacje jak wysiłek fizyczny na lekcjach wychowania fizycznego może mieć znaczący wpływ na jej rozwój [14]. Inni badacze podkreślają, że nie tylko różnorodna stymulacji ma znaczenie (zadania pamięciowe, nauka nowych informacji) ważna jest natomiast regularność podejmowanych aktywności w czasie [29]. Dzieci z grup treningowych miały możliwość regularnego i systematycznego trenowania swojej pamięci operacyjnej bardziej niż dzieci z grupy kontrolnej. Na co wskazują różnice w ilości popełnianych błędów w teście mierzącym pamięć operacyjną. Najmniej błędów w drugim pomiarze miały dzieci z grupy Mapami Myśli, średnią ilość błędów miały dzieci w grupie Notatki Rysunkowej a najwięcej błędów miały wciąż dzieci w grupie Kontrolnej. Wartym zaznaczenia jest również fakt, że dzieci z grupy Notatki Rysunkowej na wstępie miały najmniejszą ilość popełnianych błędów. Natomiast dzieci z grupy Mapy Myśli na wstępie miały średnio blisko dwóch błędów. Mimo tego, to stymulacja z mapami myśli okazała się najbardziej skuteczna.

Przeprowadzone badania wykazały, ze treningi metakognitywne z zastosowaniem Map Myśli i Notatką Rysunkową istotnie zmniejszają ilość popełnianych błędów w zapamiętywaniu przez dzieci. Natomiast jedynie stymulacja Mapami Myśli istotnie różnicuje wyniki uzyskane $\mathrm{w}$ grupie $\mathrm{z}$ tą stymulacją od grupy kontrolnej. Wnioski te wskazują na to, że metoda ta może stanowić istotne uzupełnienie innych form pomocy dla dzieci z diagnozą. W przyszłości warto byłoby sprawdzić wpływ treningów metagonitywnych na inne funkcje wykonawcze u dzieci z ADHD oraz zadbać o większą grupę badawczą. Bowiem kliniczna wielkość próby eksperymentalnej (3 x $N=15)$ stanowi istotne ograniczenie tych badań. Niemniej jednak przeprowadzone badanie dostarcza podstaw do dalszej eksploracji, a wzmocniona pamięć operacyjna może przekładać się na poprawę takich umiejętności dzieci z ADHD jak: poprawa w zakresie nauki pisania i czytania (zapamiętywanie prawidłowych kształtów liter), zapamiętywania i przywoływania $\mathrm{z}$ pamięci ustalonych zasad, czy lepszą orientację czasową [10].

\section{Podziękowania}

Autorka niniejszego artykułu zwraca się z podziękowaniami dla Pani dr hab. Agnieszki Kulik za nieocenioną pomoc i merytoryczne dyskusje nad czynionym tekstem naukowym.

\section{Conflict of interest}

The author has declared no conflict of interest. 


\section{References:}

1. Filippetti V., López, M. Las funciones ejecutivas en la clínica neuropsicológica infantil. Psicología desde el Caribe/ Executive functions in clinical child neuropsychology, 2013; 30: 380-415.

2. Nigg, JT, Willcutt, EG., Doyle, A E., Sonuga-Barke, E J. Causal heterogeneity in attention-deficit/hyperactivity disorder: do we need neuropsychologically impaired subtypes? Biological Psychiatry, 2005; 57(11): 1224-30. DOI: 10.1016/j. biopsych.2004.08.025

3. Barkley, RA. Attention-deficit hyperactivity disorder. A handbook for diagnosis and treatment, 3rd edn. Guilford Press, New York, 2006.

4. Dovis, S, Maric, M, Prins, Pier JM, Oord, S. Does executive function capacity moderate the outcome of executive function training in children with ADHD? ADHD Attention Deficit and Hyperactivity Disorders, 2019; 1: 1-16. DOI: 10.1007/s12402019-00308-

5. Barkley, RA. Attention-deficit hyperactivity disorder, fourth edition: A handbook for diagnosis and treatment. New York, NY: Guilford, 2014.

6. Barkley, RA. Impaired delayed responding: A unified theory of attention-deficit hyperactivity disorder. In D. K. Routh. Ed., Disruptive behavior disorders in childhood (pp. 11-57). New York, NY, US: Plenum Press, 1994. DOI: 10.1007/978-1-48991501-6_2

7. Yen CY., Ko CH., Yen CF., Wu HY., Yang MJ. The Comorbid Psychiatric Symptoms of Internet Addiction: Attention Deficit and Hyperactivity Disorder (ADHD), Depression, Social Phobia, and Hostility. Journal of Adolescent Health, 2007; 41(1): 93-98. DOI:10.1016/j.jadohealth.2007.02.002

8. Klingberg T. Training and plasticity of working memory. Trends in Cognitive Sciences, 2010; 14: 317-324. DOI:10.1016/j. tics.2010.05.002

9. Alderson RM,. Patros, CHG,. Tarle, SJ, Hudec, KL, Kasper, LJ, Lea, SE. Working memory and behavioral inhibition in boys with ADHD: An experimental examination of competing models, Child Neuropsychology, 2015; 1-18. DOI: 10.1080/09297049.2015.1105207

10. Entwistle PC., Shinaver C. Working Memory Training and Cogmed In: S. Goldstein, J. A. Naglier (Ed.), Handbook of Executive Functioning (pp. 475-498). London: Springer, 2014. DOI 10.1007/978-1-4614-8106-5

11. American Psychiatric Association. Diagnostic and statistical manual of mental disorders (5th ed.). Arlington, VA: American Psychiatric Publishing, 2013.

12. Bigorra A., Garolera M., Guijarro S., Hervas A. Long-Term FarTransfer Effects of Working Memory Training in Children with ADHD A Randomized controlled trial. European Child \& Adolescent Psychiatry, 2016; 25(8):853-867. DOI 10.1007/ s00787-015-0804-3

13. Diamond A. Executive functions. Annual Review of Psychology, 2013; 64: 135-168. DOI: 10.1146/annurevpsych-113011-143750

14. Diamond A., Lee K. Interventions shown to Aid Executive Function Development in Children 4-12 Years Old, Science, 2011; 333(6045): 959-964. D0I:10.1126/science.1204529.

15. Deja M. Trening uwagi u dzieci z ADHD - przegląd badań Psychiatria i Psychologia Kliniczna, 2017; 17(1): 63-71. DOI: 10.15557/PiPK.2017.0007

16. Antshel KM., Hier BO., Barkley RA. Executive functions theory and ADHD In: S. Goldstein, J. A. Naglier (Ed.), Handbook of Executive Functioning (107-120). London: Springer, 2014. DOI 10.1007/978-1-4614-8106-5

17. Meltzer L. Teaching Executive Functioning Processes: Promoting
Metacognition, Strategy Use, and Effort, In: S. Goldstein, J. A. Naglier (Ed.), Handbook of Executive Functioning (pp. 445-474). London: Springer, 2014. DOI 10.1007/978-1-4614-8106-5

18. Buzan T. Mind Mapping - kickstart your creativity and transform your life. BBC, London, 2009

19. Paivio, A. Dual coding theory and education. Draft chapter for the conference on "Pathways to Literacy Achievement for High Poverty Children," The University of Michigan School of Education, September 29-October 1, 2006. Pozyskano z: http://citeseerx.ist.psu.edu/viewdoc/ download?doi=10.1.1.329.7319\&rep=rep $1 \&$ t ype $=p d f$ [26.06.2019].

20. Balim AG. The Effect of Mind-Mapping Applications on Upper Primary Students' Success and Inquiry-Learning Skills in Science and Environment Education. International Research in Geographical and Environmental Education, 2013; 22(4): 337352. DOI: 10.1080/10382046.2013.826543

21. Kajka N., Szymona K. Terapia ADHD: Trening sukcesu w pracy z dzieckiem nadpobudliwym. Lublin: Wyd. Czelej, 2014.

22. Sacks-Zimmerman AL., Lerma VC. Mnemonic Techniques. In: Kreutzer J.S., DeLuca J., Caplan B. (eds) Encyclopedia of Clinical Neuropsychology. Springer, Cham, 2018.

23. Perry K., Weimar H., Bell A. Sketchnoting in School: Discover the Benefits (and Fun) of Visual Note Taking. Lanham, Rowman \& Littlefield Publishers, 2017.

24. Colombo B. Mental Imagery and Learning. In: Seel N.M. (Eds) Encyclopedia of the Sciences of Learning (pp.125-211). Springer, Boston, MA, 2012. DOI: 10.1007/978-1-4419-1428-6_68

25. Dahbi M. A Picture is Worth a Thousand Words Approach to Teaching English: Integrating Mind Maps. ELT Arab World English Journal (AWEJ), 2015; 6(1): 415-519. DOI: 10.24093/ awej/vol6no1.32

26. Kajka N. Trudności w nauce czytania i pisania u dzieci z ADHD. Szkoła Specjalna, 2018; 3: 212- 218.

27. Borkowska AR., Sajewicz-Radke U., Lipowska M., Kalka D. Bateria diagnozy funkcji poznawczych u dzieci w wieku 10-12 lat: PU1. Podręcznik. Gdańsk: PTPiP, 2016.

28. Sitnik-Wirchulska K., Izydorczyk B., Lipińska M. Wyzwania klinicznej diagnostyki psychologicznej dzieci i młodzieży. Rekomendacje konsultantów w dziedzinie psychologii klinicznej. Psychiatria i Psychologia Kliniczna, 2019; 19(1): $54-$ 62. DOI: 10.15557/PiPK.2019.0008

29. Simmering VR, Wood CM. The development of real-time stability supports visual working memory performance: Young children's feature binding can be improved through perceptual structure. Developmental Psychobiology, 2017;53: 1474-1493. DOI: $10.1037 / \operatorname{dev} 0000358$

Badania były częścią projektu doktorskiego realizowanego w ramach zadania badawczego pt. Promocja zdrowia wśród dzieci i młodzieży (z ADHD) za pomocą Map Myśli.

\section{Corresponding author}

MA Natalia Kajka

Department of Psychotherapy and Health Psychology, The John Paul II Catholic University of Lublin Al. Racławickie 14, 20-950 Lublin, Poland. Tel. + 48814453240 e-mail: nataliakajka@kul.lublin.pl 
Otrzymano: 05.11.2019

Zrecenzowano: 20.11.2019

Przyjęto do druku: 03.12.2019 